\title{
Evaluation of Autologous Hematopoietic Stem Cell Transplantation Results of the Patients with Hodgkin Lymphoma: A Single Center Experience
}

\author{
Tugba TURGUT ${ }^{1}$, Eren GUNDUZ ${ }^{2}$, O. Meltem AKAY ${ }^{2}$, Hava U. TEKE ${ }^{2}$, Ozge BOLLUK ${ }^{3}$, Zafer GULBAS ${ }^{4}$ \\ ${ }^{1}$ Eskisehir Osmangazi University Faculty of Medicine Department of Internal Medicine \\ ${ }^{2}$ Eskisehir Osmangazi University Faculty of Medicine Department of Hematology \\ ${ }^{3}$ Eskisehir Osmangazi University School of Medicine Department of Biostatistics \\ ${ }^{4}$ Anadolu Health Center Bone Marrow Transplantation Center, Eskisehir, TURKEY
}

\begin{abstract}
In this study data of 45 patients with Hodgkin lymphoma who underwent autologous hematopoietic stem cell transplantation between July 2000 and January 2012 were evaluated retrospectively. Clinical, laboratory and demographic characteristics affecting disease free survival (DFS) and overall survival (OS) were evaluated. Relapse and mortality rates in second and fifth years were also calculated. According to our results, patients in remission status before transplantation had a longer OS $(p=0.031)$ and relapse after transplantation shortened OS $(p=0.016)$. High beta 2 microglobulin level was associated with a shorter disease free survival $(p=0.042)$. Four patients (8.8\%) died and 14 patients $(31.1 \%)$ relapsed in the second year; 7 patients (\%15.5) died and 17 patients (37.7\%) relapsed in the fifth year. Median survival was 39 (6-72) months. In conclusion, autologous hematopoietic stem cell transplantation can be a salvage treatment for selected Hodgkin lymphoms patients who relapsed but it is important to evaluate prognostic factors and long term outcomes in terms of relapse and mortality after transplantation. Sharing experience from different transplantation centers can help selecting the most suitable patient for autologous transplantation.
\end{abstract}

Keywords: Hodgkin lymphoma, Autologous transplantation, Hematopoietic stem cells, Prognosis, Survival

\section{ÖZET}

Otolog Hematopoetik Kök Hücre Nakli Yapılan Hodgkin Lenfomalı Hastalara Ait Sonuçların Değerlendirilmesi: Tek Merkez Deneyimi

Bu çalışmada Temmuz 2000 ve Ocak 2012 arasında otolog hematopoetik kök hücre nakli yapılan Hodgkin lenfomalı 45 hastaya ait veriler geriye dönük olarak incelendi. Hastalıksız sağkalım ve genel sağkalımı etkileyen klinik, laboratuvar ve demografik özellikler değerlendirildi. İkinci ve beşinci yıllardaki relaps ve mortalite oranları da hesaplandı. Sonuçlarımıza göre, nakil öncesi remisyonda olan hastalarda genel sağkalım daha uzundu ( $p=0.031$ ) ve nakil sonrası relaps genel sağkalımı kısaltmaktaydı $(p=0.016)$. Yüksek beta 2 mikroglobulin düzeyi daha kısa hastalıksız sağkalımla ilişkiliydi ( $p=0.042)$. İkinci yılda 4 hasta (\%8.8) kaybedildi ve 14 hastada relaps gözlendi (\%31.1). Beşinci yılda 7 hasta (\%15.5) kaybedildi ve 17 hastada (\%37.7) relaps gözlendi. Ortanca sağkalım 39 (6-72) aydı. Sonuç olarak, otolog hematopoetik kök hücre nakli relaps olan seçilmiş Hodgkin lenfomalı hastalar için bir kurtarma tedavisi olabilir fakat nakil sonrası relaps ve mortalite yönünden prognostik faktörler ve uzun dönem sonuçların değerlendirilmesi önemlidir. Farklı merkezlere ait tecrübelerin tartışımasının otolog nakil için en uygun hastaların seçilmesine yardım edebileceği kanaatindeyiz.

Anahtar Kelimeler: Hodgkin lenfoma, Otolog nakil, Hematopoetik kök hücreler, Prognoz, Sağkalım 


\section{INTRODUCTION}

Hodgkin lymphoma (HL) constitutes $14 \%$ of all lymphoma cases and $1 \%$ of all cancer cases. It is possible to provide a long-term survival and even cure for over $80 \%$ of the patients. ${ }^{1}$ Relapsed disease is progression of the disease after remission with primary treatment and is seen in 10-30\% of patients. However, refractory disease is the progression of disease during primary treatment and/ or within 3 months after treatment. Relapsed disease continues to be the most important problem for the patients with HL both early and advanced stage and is seen in 5-10\% of patients. Relapsed disease is mostly seen within 1-5 years. ${ }^{2,3}$ Autologous hematopoietic stem cell transplantation (AHSCT) has become a standard approach for refractory or relapsed disease. In this study, our aim was to evaluate our own transplantation results and determine the prognostic factors affecting transplantation results.

\section{PATIENTS AND METHODS}

In this study, the results of 45 patients with Hodgkin lymphoma who underwent autologous hematopoietic stem cell transplantation between July 2000 and January 2012 were evaluated retrospectively.

As routine laboratory parameters; complete blood count, blood glucose, electrolytes, blood urea nitrogen, creatinine, liver enzymes, total protein, albumin, total and direct bilirubin, erythrocyte sedimentation rate (ESR), C-reactive protein (CRP), beta-2 microglobulin, immunoglobulin $\mathrm{G}, \mathrm{A}$ and $\mathrm{M}$ levels have been studied.

As transplant-related parameters; the amount of stem cells given, duration between stem cell collection and transplantation, duration between last treatment and transplantation, time of platelet engraftment, time of neutrophil engraftment, treatments given after transplantation and relapse after transplantation have been evaluated. The study has been approved by the appropriate ethics committe and have therefore been performed in accordance with the ethical standards in Declaration of Helsinki. Surviving patients gave their informed consent prior to inclusion in the study.
Data were analyzed using SPSS statistical software 15. Kaplan-Meier survival analysis was used for survival analysis. Survival was calculated as the time between the day of stem cell infusion and the death or last follow up. Cox regression test and multivariate regression analysis were used in determination of the factors affecting mortality and relative risks. Demographic characteristics, laboratory and transplantation parameters were analyzed using Cox regression (Backward Stepwise Wald) analysis.

\section{RESULTS}

Patient characteristics are shown in Table 1. Fortyone patients $(91.1 \%)$ had no accompanying diseases but 4 patients $(8.9 \%)$ had diabetes mellitus $(n=2)$, Raynaud's phenomenon $(n=1)$ and cerebral infarction $(n=1)$.

\begin{tabular}{|c|c|}
\hline & n (\%) \\
\hline Patient number & 45 (100) \\
\hline \multicolumn{2}{|l|}{ Gender } \\
\hline Female & 16 (35.6) \\
\hline Male & $29(64.4)$ \\
\hline \multicolumn{2}{|l|}{ Histological type } \\
\hline Nodular sclerosing & $28(62.2)$ \\
\hline Mixed cellular & $10(22.2)$ \\
\hline Lymphocyte rich & $3(6.7)$ \\
\hline Nodular lymphocyte predominant & $3(6.7)$ \\
\hline Lymphocyte poor & $1(2.2)$ \\
\hline \multicolumn{2}{|l|}{ Stage at diagnosis } \\
\hline । & $1(2.2)$ \\
\hline$\|$ & $12(26.6)$ \\
\hline III & $20(44.4)$ \\
\hline IV & $10(22.2)$ \\
\hline \multicolumn{2}{|l|}{ Extranodal involvement } \\
\hline Yes & $13(28.9)$ \\
\hline No & $32(71.1)$ \\
\hline \multicolumn{2}{|l|}{ Remission status at the time of AHSCT } \\
\hline Complete remission & $31(68.9)$ \\
\hline Partial remission & $14(31.1)$ \\
\hline \multicolumn{2}{|l|}{ Radiotherapy before AHSCT } \\
\hline Yes & $9(20)$ \\
\hline No & $36(80)$ \\
\hline
\end{tabular}




\begin{tabular}{|ll|}
\hline \multicolumn{2}{|l|}{ Table 2. Mobilization regimens } \\
\hline Mobilization regimen & $\mathbf{n}(\%)$ \\
\hline G-CSF & $22(48.9)$ \\
DHAP + G-CSF & $11(24.4)$ \\
Cyclophosphamide + G-CSF & $11(24.4)$ \\
Etoposid + G-CSF & $1(2.2)$ \\
TOTAL & $45(100)$ \\
\hline G-CSF:Granulocyte colony stimulating factor \\
DHAP: dexamethasone, cytarabine, cisplatin \\
\end{tabular}

The average time between last treatment and $\mathrm{AH}-$ SCT was 2.7 (1-8) months. In all patients, BEAM protocol (melphalan $140 \mathrm{mg} / \mathrm{m}^{2}$ iv, cytarabine $2 \mathrm{x}$ $200 \mathrm{mg} / \mathrm{m}^{2}$ iv, etoposid $200 \mathrm{mg} / \mathrm{m}^{2}$ iv, BCNU 300 $\mathrm{mg} / \mathrm{m}^{2} \mathrm{iv}$ ) was used as a conditioning regimen.

Patients were routinely examined in terms of thrombophilia before transplantation. One patient (2.2\%) had low protein C level, 4 patients $(8.9 \%)$ had low protein $\mathrm{S}$ level, 4 patients $(8.9 \%)$ had lupus anticoagulant positivity, 2 patients $(4.4 \%)$ had activated protein $\mathrm{C}$ resistance. However, no arterial and/or venous thrombosis during or after transplantation was observed in these patients. In microbiological testing all patients were negative for hepatitis C and HIV antibody. Hepatitis B surface antigen was positive in two patients (4.4\%).

Mobilization regimens are shown in Table 2. Transplantation-related data are summarized in Table 3. Treatments for febrile neutropenia are shown in Table 4.

\begin{tabular}{|lc|}
\hline Table 4. Treatment for febril neutropenia & \\
\hline & $\mathbf{n}(\%)$ \\
\hline None & $3(6.7)$ \\
Antibiotics & $34(75.6)$ \\
Antibiotics + Antifungal & $7(15.6)$ \\
Antibiotics + Antifungal + Antiviral & $1(2.2)$ \\
Total & $45(100)$ \\
\hline
\end{tabular}

\begin{tabular}{|ll|}
\hline Table 3. Transplantation related data & \\
\hline & $\begin{array}{l}\text { Median } \\
\mathbf{( 2 5 \% - 7 5 \% )}\end{array}$ \\
\hline Stem cell account (x106 CD34+cell /kg) & $4.84(4.2-5.5)$ \\
Neutrophil engraftment time (+. day) & $9(9-10)$ \\
Platelet engraftment time (+. day) & $10(9-11)$ \\
Time between stem cell collection & $2(2-3)$ \\
and transplantation (month) & \\
Duration of hospitalization (day) & $30(26-38)$ \\
\hline
\end{tabular}

After AHSCT 17 patients (37.8\%) relapsed. The median time until relapse was 6 (5-24) months. Thirty-seven patients $(82.2 \%)$ were in complete remission, 8 patients $(17.8 \%)$ were in partial remission. Five patients $(29.2 \%)$ received only chemotherapy, 3 patients $(17.6 \%)$ received chemotherapy plus radiotherapy, 9 patients $(53.2 \%)$ underwent non-myeloablative allogeneic hematopoietic stem cell transplantation for relapse after AHSCT.

Thirty four of the patients (75.6\%) were alive. Eight patients died (17.8\%) because of relapse and 3 patients $(6.7 \%)$ died because of non- lymphoma reasons. Overall survival (OS) was $140.9 \pm 10.4$ months, disease free survival (DFS) was $89.93 \pm$ 5.41 months (Figure 1). The number of patients who died within the first 100 days was 1 and he died because of infection. Four patients $(8.8 \%)$ died in the second year and 7 patients $(15.5 \%)$ died in the fifth year. 14 patients $(31.1 \%)$ relapsed in the second year and 17 patients $(37.7 \%)$ relapsed in the fifth year after transplantation. Median survival was 39 (6-72) months. According to Kaplan-Meier analysis, survival ratio was $44 \%$ during 96 months and 59\% during 140 months from diagnosis. Survival after transplantation was $59.4 \pm 5.9$ months in relapsed patients (Figure 2).

When age, stage of disease at the time of diagnosis, radiotherapy before transplantation, extranodal involvement at the time of diagnosis and remission before transplantation were analyzed it was found that the factor determining the risk of death was remission before transplantation $(\mathrm{p}=0.031)$. The other parameters were not found statistically sig- 
nificant. It was found that remission increased risk of death 3.95 times $(\mathrm{OR}=1 / 0.265=3.77)$.

When laboratory findings with possible prognostic significance was examined using Cox regression analysis, the only factor effecting DFS was found to be beta- 2 microglobulin $(p=0.042)$ and increased the risk of death 1.56 fold.

When the parameters related with transplantation were analyzed; stem cell count, time between stem cell collection and transplantation, time of neutrophil engraftment and presence of relapse were found to be significant in terms of DFS ( $\mathrm{p}=$ $0.041)$ but only relapse was statistically significant in terms of OS $(\mathrm{p}=0.016)$ and it was found that relapse increased the risk of death 6.86 times.

\section{DISCUSSION}

In this study, demographic, clinical, prognostic and transplantation related characteristics of our HL patients who underwent AHSCT in our transplantation center were evaluated.

There are several studies evaluating the long-term results of AHSCT and factors affecting these results in patients with Hodgkin lymphoma. ${ }^{4-13}$ Unlikely; effects of gender, bone marrow involvement at diagnosis, histology, conditioning regimen, origin of stem cells, mobilization regimen, year of transplantation and immunotherapy were not analyzed in our study. Patient numbers were not enough for making a comparison between groups for some parameters. Conditioning regimen and origin of stem cells were same for all patients. None of our patients received immunotherapy.

Forty to sixty percent of patients treated with $\mathrm{AH}-$ SCT can be expected to be alive at 5 years from the time of transplantation. Relapse and progression remain the main cause of transplantation failure. Long term outcomes of patients who survive in remission for at least 2-years and risk factors for late relapse are not well known. The results of the studies determining the prognostic factors affecting the long term survival and relapse demonstrate that most of the relapses occur within the first two years and all relapses occur in 5 years. All patients who were alive and disease free at 5 years were still in remission at 10 years post-transplant. ${ }^{7,14-15}$ This was similar in our study, none of the patients relapsed after 5 years.

Nachbaur et al. ${ }^{6}$ described that stage at transplantation was the most powerful parameter affecting OS, DFS and relapse for HL patients who underwent AHSCT. Sureda et al. ${ }^{12}$ examined the longterm prognostic data in a multivariate analysis, total body irradiation and AHSCT time (before 1995) were identified as independent risk factors for non-relapse mortality. Sucak et al. ${ }^{16}$ analyzed the data of relapsed and/or refractory HL patients who underwent AHSCT and found that chemosensitive relapse is the most important prognostic factor on OS and DFS. In our study, relapse after transplantation was also found to affect OS negatively $(p=0.016)$. In addition, shorter DFS was associated with high beta 2 microglobulin level before transplantation $(\mathrm{p}=0.02)$. In our study lactate dehydrogenase (LDH) was not associated with prognosis like many other studies. We think that the reason for this might be the remission status of our patients. Most of our patients (68.9\%) were in complete remission and had normal LDH levels. Although ESR, CRP and albumin affected DFS, this effect was not statistically significant. This may be due to the same reason for $\mathrm{LDH}$.

When disease status at transplantation and bulky disease were examined they were found to be important factors affecting survival in many studies. ${ }^{15,17-19}$ In our study, remission status at transplantation was found to be statistically significant for OS ( $p=0.031)$. Different studies had different results about remission status and that could be grounded on applying different chemotherapy regimens before transplantation. Nachbaur et al. ${ }^{6}$ described that incidence of relapse changes according to remission status at transplantation. The cumulative incidence of relapse was $30 \%$ even for patients in complete remission at time of AHSCT, $44 \%$ for the chemosensitive patients who are not in complete remission and $40 \%$ for refractory patients. These two factors were also found as prognostic factors in our study. Same authors also described that BEAM conditioning regimen was predictive for favourable outcome, better disease-/progression free survival and a significantly lower risk of 
relapse. In our study, all patients received BEAM regimen and stem cell resource was peripheral blood so these parameters were not evaluated as a prognostic factor.

Sureda et al. ${ }^{12}$ found 5 -year OS was $57 \% \pm 3 \%$. Nachbaur et al. ${ }^{6}$ found OS was $56 \%$ with a disease-/ progression- free survival of $49 \%$ following $\mathrm{AH}-$ SCT. Majhail et al. ${ }^{21}$ found OS at 10 -years $77 \%$. In our study, OS was $44 \%$ in 96-month follow-up period and was 59\% in 140 months follow-up period.

In conclusion, AHSCT can be a salvage treatment for selected patients who relapsed after first treatment but it is important to evaluate prognostic factors and long term follow-up in terms of relapse and mortality. It can contribute to proper patient selection if transplant centers share their experience in the transplantation era.

\section{REFERENCES}

1. Philip Lanzkowsky. Manuel of Pediatric Hematology and Oncology, 4 th ed. New York, Elsevier, 2010 :453- 490.

2. Horning S. Hodgkin's disease. In: Cavalli F, Hansen HH, Kaye S (eds), Textbook of Medical Oncology (2nd ed). London, Martin Dunitz Publishers, 2000: 461-474.

3. Diehl V, Mauch PM, Harris NL. Hodgkin's disease. In: De Vita VT, Hellman S, Rosenberg SA (eds), Principles and Practice of Oncology (6th ed). Philadelphia, Lippincott Williams \& Wilkins, 2001: 2339-2386.

4. Kako S, Izutsu K, Kato K, et al. The role of hematopoetic stem cell transplantation for relapsed and refractory Hodgkin lymphoma. Am J Hematol 90: 132-138, 2015.

5. Witzens-Harig M, Heilmann C, Hensel M, Kornacker M. Longterm follow-up of patients with non-Hodgkin lymphoma following myeloablative therapy and autologous transplantation of CD34 \pm selected peripheral blood progenitor cells. Stem Cells 25: 228-235, 2007.

6. Nachbaur D, Greinix HT, Koller E, et al. Long-term results of autologous stem cell transplantation for Hodgkin's disease (HD) and low-/intermediate-grade B non-Hodgkin's lymphoma (NHL): a report from the Austrian Stem Cell Transplantation Registry (ASCTR). Ann Hematol 84: 462-473, 2005.

7. Majhail NS, Bajorunaite R, Lazarus HM, et al. Long-term survival and late relapse in 2-year survivors of autologous haematopoietic cell transplantation for Hodgkin and nonHodgkin lymphoma. Br J Haematol 147: 129-139, 2009.

8. Kuittinen $\mathrm{T}$, Wiklund $\mathrm{T}$, Remes $\mathrm{K}$, et al. Outcome of progressive disease after autologous stem cell transplantation in patients with non-Hodgkin's lymphoma: a nation-wide survey. Eur J Haematol 75: 199-205, 2005.

9. Bertz $\mathrm{H}$, Zeiser R, Lange W, et al. Long-term follow-up after high-dose chemotherapy and autologous stem-cell transplantation for high-grade B-cell lymphoma suggests an improved outcome for high-risk patients with respect to the age-adjusted International Prognostic Index. Ann Oncol 15: 1419-1424, 2004

10. Bolwell B, Kalaycio M, Sobecks R, et al. Autologous hematopoietic cell transplantation non- Hodgkin's lymphoma: 100 month follow-up. Bone Marrow Transplant 29: 673-679, 2002.

11. Mounier N, Gisselbrecht C, Brière J, et al. Prognostic factors in patients with aggressive non-Hodgkin's lymphoma treated by front-line autotransplantation after complete remission: a cohort study by the Groupe d'Etude des Lymphomes de l'Adulte. J Clin Oncol 22: 2826-2834, 2004.

12. Sureda $\mathrm{A}$, Constans $\mathrm{M}$, Iriondo $\mathrm{A}$, et al. Prognostic factors affecting long-term outcome after stem cell transplantation in Hodgkin's lymphoma autografted after a first relapse. Ann Oncol 16: 625-633, 2005

13. Paltiel $\mathrm{O}$, Rubinstein $\mathrm{C}$, Or R, et al. Factors associated with survival in patients with progressive disease following autologous transplant for lymphoma. Bone Marrow Transplant 31: 565-569, 2003.

14. Van Besien K, Tabocoff J, Rodriguez M, et al. High-dose chemotherapy with BEAC regimen and autologous bone marrow transplantation for intermediate grade and immunoblastic lymphoma: durable complete remissions, but a high rate of regimen-related toxicity. Bone Marrow Transplant 15: 549-555, 1995

15. Wadehra N, Farag S, Bolwell B, et al. Long-term outcome of Hodgkin disease patients following high-dose busulfan, etoposide, cyclophosphamide, and autologous stem cell transplantation. Biol Blood Marrow Transplant 12: 13431349, 2006.

16. Sucak GT, Cakar MK, Suyani E, et al. Outcome of autologous stem-cell transplantation in relapsed or refractory Hodgkin lymphoma patients in a centre from Turkey. Hematology 14: 134-136, 2013.

17. Majhail NS, Weisdorf DJ, Defor TE, et al. Long-term results of autologous stem cell transplantation for primary refractory or relapsed Hodgkin's lymphoma. Biol Blood Marrow Transplant 12: 1065-1072, 2006. 
International Journal of Hematology and Oncology

18. Majhail NS, Bajorunaite R, Lazarus HM, et al. Long-term survival and late relapse in 2-year survivors of autologous haematopoietic cell transplantation for Hodgkin and nonHodgkin lymphoma. Br J Haematol 147: 129-139, 2009.

19. Lavoie JC, Connors JM, Phillips GL, et al. High-dose chemotherapy and autologous stem cell transplantation for primary refractory or relapsed Hodgkin's lymphoma: long-term outcome in the first 100 patients in Vancouver. Blood 106: 14731478,2005

20. Horning SJ, Chao NJ, Negrin RS, et al. High-dose therapy and autologous hematopoietic progenitor cell transplantation for recurrent or refractory Hodgkin's disease: analysis of the Stanford University results and prognostic indices. Blood 89 : 801-813, 1997.

21. Majhail NS, Bajorunaite R, Lazarus $\mathrm{H}$, et al. Long term survival and late relapse in 2-year survivors of autologous haematopoetic cell transplantation for Hodgkin and non-Hodgkin lymphoma. Br J Haematol 147: 129-139, 2009.

\section{Correspondence}

\section{Dr. Eren GÜNDÜZ}

Eskisehir Osmangazi Universitesi

Tıp Fakültesi

Hematoloji Anabilim Dalı

26480 Eskisehir, Turkey

Tel: (+90.222) 2398466

Fax: (+90.222) 2393774

e-mail: erengunduz26@hotmail.com 